\title{
LOCAL TREATMENT OF LEACHATE FROM MSW LANDFILLS USING SOIL PLANT - SYSTEM
}

\author{
Lars Thörneby \\ University of Kalmar, Sweden \\ William Hogland \\ University of Kalmar, Sweden \\ Erling Alm, Anders Lindén \\ AB ASSY, Sweden \\ Hans Dahl, Roland Warme
} Kalmar Vatten och Renhällning $A B$, Sweden

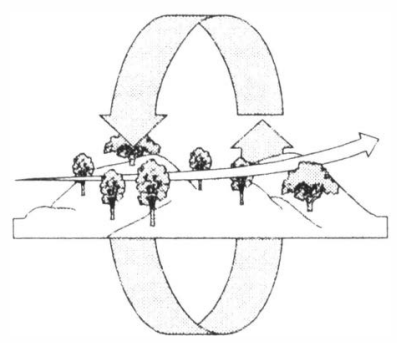




\begin{abstract}
Landfill leachate is identified as an environmental concern, as it contains both eutrophicating and harmful substances. Collection and treatment of leachate is therefore a necessity and most landfills in Sweden treat the leachate before discharge into any recipient. More and more landfills changes to local treatment and at Moskogen and Hedeskoga landfills Soil-Plant (SP) systems were designed to replace the conventional treatment of leachate at the municipal sewage treatment plant.

Installed in 1998, the SP-system at Moskogen have removal efficiency today for some key parameters of about: $97 \%$ for BOD; $41 \%$ for COD; and for $\mathrm{NH}_{4}-\mathrm{N} 99 \%$. The SP-system at Hedeskoga was planted with cuttings (Salix) in the spring of 1999 and the system was put into operation in the summer and the removal efficiencies for pollutants in the ponds was in July for: BOD $80 \%$; COD 65\%; Tot-N 87\%; and $\mathrm{NH}_{4}-\mathrm{N} 94 \%$.
\end{abstract}

Keywords: Soil-Plant system, leachate, treatment, hydrology, evapotranspiration, pollution removal, pre-treatment 


\section{Introduction}

In Sweden there are about 300 municipal landfills receiving about 5 million tons of waste annually. The size of the individual landfill varies depending on the collection area and about 50 percent of the landfilled waste are landfilled at 25 landfills while 175 small landfills only receive 10 percent of the waste.

One of the major environmental problems facing landfill operators is the management of leachate because it contains a variety of pollutants including persistant organic compounds and heavy metals. Landfill leachate has by that the potential to contaminate surface and subsurface waters. During the 50's and 60's very little attention took place concerning emissions to air and water from landfills. In most cases the landfill owner relied on natural attenuation of leachate contaminants and no efforts were made to collect or treat the leachate. Later on, during the 70's, people began to suggest environmental concern and many landfills was supplied with collection systems for the leachate and the collected leachate was then sent to the municipal treatment plant for co-treatment with the sewage. Today, the leachate from more than 80 percent of these landfills undergoes some kind of treatment. For about 100 landfills the leachate is lead to the municipal wastewater treatment plant. The Swedish EPA recommends local treatment of leachate.

On site treatment of leachate is today, in round numbers, implemented at 70 landfills. Most of these treatment systems are of low-tech type as: irrigation, recycling of leachate, overland flow, ponds or wetlands as conventional treatment systems involve high costs and a long-term commitment. Moreover, the great variations in strength and flows of leachate make the use of these systems undesirable. Today it seems to be irrigation of vegetation also called Soil-Plant (SP)- system, which is of most interest. A soil-plant system for treatment of leachate consists of two or more ponds and an irrigation area planted with suitable trees or bushes. The ponds should be large enough to store the entire volume of leachate produced during the nonvegetative season and the irrigated at least large enough to be irrigated by the annual leachate volume without that saturated conditions occur. Soil-plant treatment has, in Sweden, been in operation since mid 80's (Hasselgren, 1992) and today 33 landfills have SP-system and other are planning to build such a treatment system. Initially the main purpose was to reduce the leachate discharge from the landfill (Ettala, 1988) and utilise the nitrogen content as a fertiliser for production of biomass. 


\section{Methodology}

The Soil-plant system is located in southern Sweden: Hedeskoga $5 \mathrm{~km}$ north of Ystad and Moskogen landfill $15 \mathrm{~km}$ west of Kalmar. The main objectives of the project are to:

- Characterise SP-system treatment performance for metals, organics, and ammonia for future judgement if the effluent from the system can be discharged directly into receiving body.

- Investigate the convenience of locating irrigation surfaces for leachate treatment outside the landfill compared to on site.

- Establishment of control programme for treatment of leachate including health and security especially due to organic compounds.

- Identify the fate of persistant organics and metals in SP-system.

- Characterise quality of run off during snowmelting, heavy rainfalls and periods with high irrigation rate.

- Develop and evaluate construction and management practices for SP-system including design, hydraulic and pollution load etc.

- Evaluate biomass production and uptake of pollutants

The project started in late august this year and so far we have opened up one old drainage pipe at Moskogen and started to drain a part of the irrigation area. Also, lysimeters has been placed into the soil both on forested and the grassed areas. Depending on the results from these preliminary studies we aim to construct a test area with control of both influent and effluent. Lysimeters will also be placed into the soil at Hedeskoga's irrigation area during this year.

- Temperature, $\mathrm{pH}$, conductivity, dissolved oxygen and redox-potential will be measured at the storage ponds, irrigation water, percolated water (lysimeters) and at the drained water once a week.

- The SP-system at Moskogen and Hedeskoga will be sampled every week while it is operating. These samples will be analysed for, ammonia-nitrogen, nitrate $\left(\mathrm{NO}_{3}\right)$, total phosphorus, chemical oxygen demand (COD), biochemical oxygen demand (BOD) and chloride $\left(\mathrm{Cl}^{-}\right)$.

- The ratio of nitrate to ammonia-nitrogen will be monitored in the storage ponds during the operating season to determine if nitrification is occurring so that remedial action can be taken if necessary.

- Collection and working up meteorological and leachate data will be performed during the winter. 


\section{Soil-Plant system}

Soil-Plant systems are low tech, solar driven systems that are user friendly and do not require highly trained and skilled operators. SP system are capable of absorbing pollutant loadings, and in appropriate circumstances can provide a low cost alternative to chemical and biological treatment as well as more engineered systems. The main economical disadvantage of SP treatment is the cost of land for this land intensive process. Operating costs are, on the contrary, generally very low.

SP-system can either be constructed at the landfill or outside the drained landfill area. There are obvious advantages of constructing SP-system on a finished part of the landfill; less risk of ground water contamination; more leachate can be removed as the supply of water from precipitation fall on the same area which produce leachate and less costs for land. The landfill gas production can also increase if water infiltrate through the SP-system down to the waste.

Construction of a SP-system outside the drained area include some risks as it is not fully investigated to which extent a SP-system works as a treatment method for leachate in terms of removal of contaminants. Even if surface water is more readily exposed to pollutants from human activities, for example, than groundwater is, this by no means says that groundwater is invulnerable to contamination. Once groundwater is contaminated, it is an extremely difficult and costly operation to remove the contaminants. Any chemicals that are easily soluble and penetrate the soil at the irrigation area are prime candidates for groundwater pollutants.

\section{Pre-treatment}

Mostly, some pre-treatment of leachate before irrigation is necessary for technical reasons. Raw leachate generally contains dissolved solids that will precipitate in pumps, pipes and sprinklers causing unacceptable maintenance costs. Pre-treatment of the leachate also decreases $\mathrm{BOD}, \mathrm{NH}_{4}-\mathrm{N}$ and volatile organic compounds giving a more suitable irrigation water. Less oxygen demanding compounds in the water will give the possibility of aerobic environment in the upper part of the soil even at occasionally saturated conditions. Also, ammonia-nitrogen transformed to nitrate reduces nitrogen losses to the atmosphere when sprinkling the leachate. The overall quality of the leachate will increase as many inorganics (metals) may co-precipitate with iron and end up in the pond sediment.

\section{Pollution removal}

The irrigated area in a SP system can be compared to vertical flow "wetlands" or intermittent gravel filters, which have demonstrated advantages for oxygen transfer and nitrogen control. The system includes several physical, chemical and biological processes.

Involved in water quality improvement are:

in the ponds 
- sedimentation

- precipitation

- bacterial (and alga) metabolism

at the irrigated area

- natural filtration

- precipitation

- adsorption

- bacterial and plant metabolism

- plant uptake -harvesting

Vertical filter with soil substrate removes dissolved nutrients as nitrogen and phosphorus and organic matter in terms of BOD and COD. Nitrogen removal is a two step process; first nitrification when bacteria convert ammonium $\left(\mathrm{NH}_{4}+\right)$ into nitrite $\left(\mathrm{NO}_{2}{ }^{-}\right)$and nitrate $\left(\mathrm{NO}_{3}{ }^{-}\right)$ under aerobic conditions; secondly denitrification when other species of bacteria convert nitrate into nitrogen gas $\left(\mathrm{N}_{2}\right)$. The latter process occurs under anaerobic conditions and the produced nitrogen gas is then released into the atmosphere. The aeration and irrigation processes may in some cases contribute to nitrogen removal by ammonia volatilisation.

Dissolved phosphorus is removed by adsorption, complexation and precipitation with dissolved minerals and by peat accretion (accumulation of organic matter) (Brix, 1994). Removal efficiencies in a vertical wetland filter of $40 \%, 100 \%$ and $90 \%$ has been reported for nitrogen, phosphorus and BOD respectively (Wittgren, 1988). At this point in the development of SP technology there are very sparely with data on pollutant reductions, probably due to the difficulty to measure effluents, as there are no point sources. However, some data exist and nitrogen removal above $90 \%$ has been reported from some landfills. At one Swedish landfill the reduction of nitrogen was $95 \%$, phosphorus $83 \%$, and COD $62 \%$ (Dilip, 1999). Caution must, however be taken when evaluating removal efficiencies for $\mathrm{BOD}, \mathrm{COD}$ and total suspended solids (TSS) as the presence of naturally-occurring organics in the irrigated area, make it not possible to achieve complete removal of BOD, COD and TSS.

Heavy metals are removed by precipitation and sedimentation in the ponds, by filtration, ion exchange, adsorption and chelation in the soil and by plant uptake. Heavy metals removed from the leachate by SP- system may then accumulate in pond sediment, soil and vegetation. However, changes in the environmental conditions of the SP-system may cause heavy metal to resolve and finally end up in the ground water. These changes might for instance be anareobic conditions created by excessive irrigation in a former aerobic upper layer of the soil where metals have been trapped. Heavy metals may also be recycled into the ecosystem by animals and detritus.

\section{Hydrological considerations}

SP-system is like other natural treatment system highly influenced by the hydrologic conditions at the site. Precipitation, evapotranspiration, soil properties and ground water flow are all factors among others that influence treatment efficiency. The vertical flow and storage 
volume determine the length of time that water spends in the active part of the soil profile and thus the opportunity for interactions between water borne substances and the forest ecosystem. Water enters SP-system via precipitation, irrigation and sometimes groundwater discharge and run on. SP-system loses water via run off, groundwater recharge, and evapotranspiration. Landfill water balance is important for design of SP-system and evapotranspiration (ET) and soil properties are important factors in SP-system performance.

\section{Water balances}

Calculation of water balances for the landfill, storage ponds and irrigated areas at both sites will be performed in order to create a basis for judgement of SP performance for the two different locating possibilities. In Figure 1 shows some of the various components of water moisture used in water budget calculations for landfills.

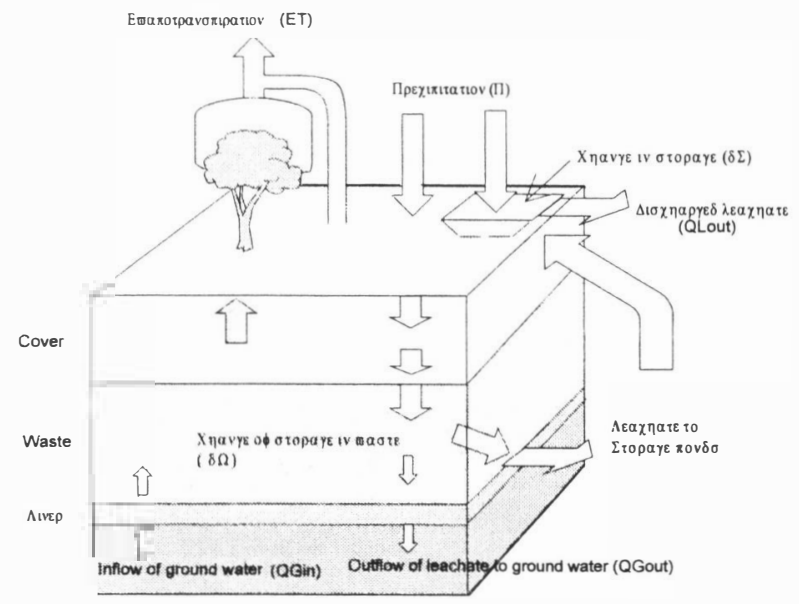

Figure1. Water balance parameters for the landfill.

The water balance for the landfill can be written as:

$$
P+Q G i n=E T+Q L o u t+Q G o u t+d W+d S
$$

where

$P=$ Precipitation

$Q G i n=$ Ground water inflow

QGout $=$ Ground water outflow

$d W=$ Change of storage in the waste

$d S=$ Change of storage in the storage ponds

The water balance for the detention ponds can be written as:

$$
P P+Q \text { Lin }+Q \text { Gin }=E+Q L o u t+Q G o u t+d S
$$


where

$$
\begin{aligned}
& P P=\text { Precipitation at the ponds } \\
& E=\text { Evaporation } \\
& Q L \text { in = Leachate inflow }
\end{aligned}
$$

The water balance for the irrigated area (Figure 2) can be written as:

$$
P I+I+Q G i n+R i n=E T+Q P+Q G o u t+R o u t+d S M
$$

where

$P I$ a Precipitation at the irrigated area

$I=$ Leachate supply (irrigation)

$d S M=$ Change in soil moisture

Rin $=$ Surface water supply from adjacent areas

Rout $=$ Run off from irrigated area

$Q P=$ Percolated water

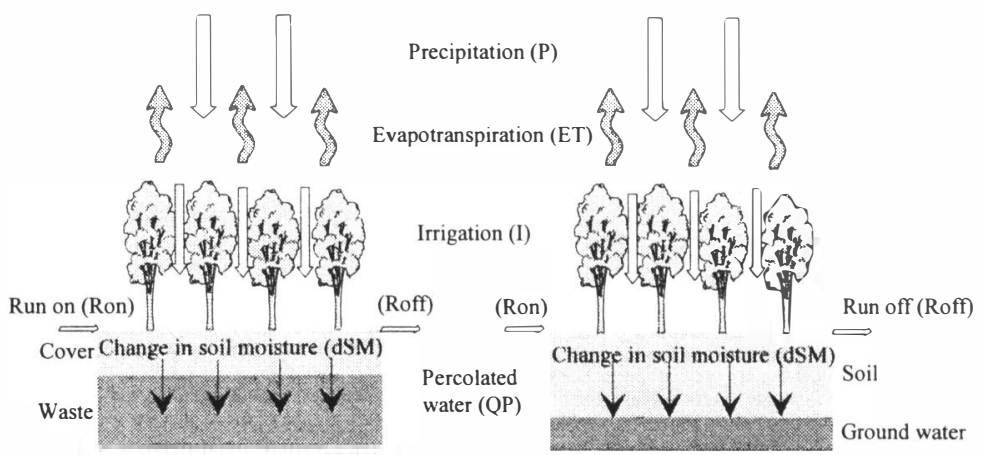

Figure 2 Water balance parameters for on-site (left) and off-site (right) SP areas.

\section{Evapotranspiration}

Water loss by evapotranspiration has great importance for the performance of the SPsystem. To which extent evaporation occur during dry periods depend on the magnitude of available energy at soil and leaf surfaces and the water vapour gradient between these surfaces and air. The components of the energy balance (radiation flux - solar and thermal; sensible heat flux -turbulent transfer or heat from the surface to the atmosphere; latent heat flux - evaporative cooling or warming upon condensation and soil heat flux) determine the net energy supply to the leaf and the surface, and thereby determine the evaporation rate. The vapour pressure gradient at surface must exceed that of the air otherwise no evaporation occur. Hence, evaporation is zero during rainfall and other occasions when relative humidity is near saturation and high during dry and windy conditions.

Large evaporation rates have been documented for leachate irrigated willow. The mean value of evapotranspiration rate for a three years old willow stand was $4.2 \mathrm{~mm} / \mathrm{d}$ (Hasselgren, 1992), 


\section{Vertical flow}

Atmospheric ET losses serve to slow the vertical flow, and increase detention time, rainfall and irrigation has the opposite effect. In order to prevent pollution of groundwater are SPsystem outside the landfill equipped with a downstream drainage system. Unfortunately it is difficult to equal the irrigation with losses by evapotranspiration, thus at periods with intense precipitation it can be necessary to return large amounts of water to the storage ponds. In order to optimise water losses the supply of water should be close to the evapotranspiration but excessive irrigation may cause saturation of the soil and thus depletion of plant growth. Because of the importance of the detention time, some attention to the soil properties must be taken.

Some on- site SP system are planted directly in the top cover material but in most cases 20 $30 \mathrm{~cm}$ top- soil or compost is added before planting. The hydraulic conductivity of the soil can decrease by deposition of solids from the irrigated water. This solids can either emanate from suspended solids in the water or from dissolved solids precipitating in the soil environment. Also, organic matter from forest environment, as dead leaves harvest residues etc. might contribute to soil clogging. Furthermore root growth also reduces the available pore space mainly in the upper part of the soil. The high sensitivity of hydraulic conductivity to void fraction. result in a large decline in hydraulic conductivity even at moderate void blockage. For example, a $2 \%$ void blockage can result in a $10 \%$ conductivity drop.

There is no uniform flow pattern in the soil, which is important to notice when calculating detention time. There are disturbances as preferential flow channels, surface flow, mixing of water due to delays or transverse mixing. There is also an interaction between spatial patterns of roots and patterns of water movement. The effects of these disturbances in flow patterns on pollutant reduction can be quite important. Fast moving water parcels interact weakly with soil, bacteria and roots, and depart the SP.system with little chemical alteration. Slow moving parcels interact strongly, and depart with greatly altered chemistry.

\section{Thermal considerations}

The irrigation period is in most cases equal to the vegetation period even if it would be possible to reduce pollutants during the winter season. Risk of ice formation at tree stems and in pumps and pipes and not pollutant removal is the main reason for chose of irrigation period

The temporal pattern of SP-system water temperatures is that of cycles within cycles: diumal cycles reflecting the influence of solar radiation; and annual cycles, reflecting the seasonal changes in insolation. Biochemical processes are temperature sensitive, and slow considerably in cold water, hence the water temperature in the SP-system controls the rate of removal of BOD, ammonia/ammonium and nitrate. Most sensitive for cold temperatures are the microbially mediated nitrogen processes. Studies of wetland filter show high BOD removal during winter period and lowered but significant removal of nitrogen even when water temperature was close to zero. During periods of low temperature the nitrogen leached out as nitrate (Wittgren, 1988). The solubility of oxygen in water is also temperature dependent and the increased oxygen supply will to some extent counteract low temperatures. 


\section{Mass Balance}

It is difficult to perform a mass balance of pollutants in common SP-systems, as there is no defined outlet, and by this be able to evaluating the true performance of the system (as is often done for municipal wastewater treatment systems). A mass balance approach would not only allows for a better assessment of the system's performance, it also would facilitates comparison among systems and be used to determine parameters for future designs. In order to create a point effluent and thereby make mass balance calculations possible a drained test area of about 200-400 $\mathrm{m}^{2}$ will be constructed at Moskogen landfill.

A general mass balance can be simply described as follows:

$$
\text { Min }=\text { Mout }+ \text { Msto }+ \text { Mrem }
$$

where

$$
\begin{aligned}
& \text { Min = the mass of pollutant input } \\
& \text { Mout = the mass of pollutant output; } \\
& \text { Mrem = the mass of pollutant removed; } \\
& \text { Msto = the mass of pollutant temporarily stored in the system. }
\end{aligned}
$$

Both the mass coming "In" and "Out" of the irrigated area are calculated by multiplying the measured concentration by the flow rate (giving $\mathrm{kg}$ of pollutant per $\mathrm{m}^{3}$ per day).

The "Storage" is the change in pollutant concentration within the system at any given time. The mass in Storage depends on soil moisture and the temporarily storage of compounds in the biomass and the soil. The ideal method for determining storage would involve developing mathematical models describing the soil moisture and the temporarily storage of the various pollutants. The pollutants are also more or less temporarily stored in the system. Once the mass of pollutant loaded In to and discharging Out of the irrigated area as well as that in Storage are calculated, the Removal can be determined.

The advantage of using such a model is that it allows for the comparison of SP areas of various designs loaded with wastewater of various strengths. The idea is to test various models, then use that model which best describes the data in the mass balance to determine design parameters. For that reason, extensive data will be collected from the test areas at Moskogen and Hedeskoga.

\section{Description of study areas}

\section{The Moskogen landfill}

The Moskogen landfill receives waste from Kalmar and its surroundings. Before 1998 all leachate was piped to the municipal wastewater treatment plant in Kalmar. The annual leachate production at Moskogen landfill, Kalmar was about $90,000 \mathrm{~m}^{3}$ in 1998 . Today the drained area is extended and the leachate production has increased with $10-15$ percent to 100,000-11a,000 m . 
In order to meet authorities demand for treatment of leachate at the site of production a 10 ha SP system was constructed. Layout of the SP treatment system consists of three ponds, a parcel of land (Figure 3) located outside the southeast corner of the landfill planted with willow and a part of the old landfill covered with grass. Leachate is collected in the three ponds and then pumped and distributed over the two irrigation areas. The three storage ponds having a total area of approximately 7 ha is sited on the drained landfill area. The site outside the landfill is approximately $500 \mathrm{~m}$ in length and $200 \mathrm{~m}$ in width having a surface area of $9 \mathrm{ha}$ and the energy grass area has an area of 3 ha.

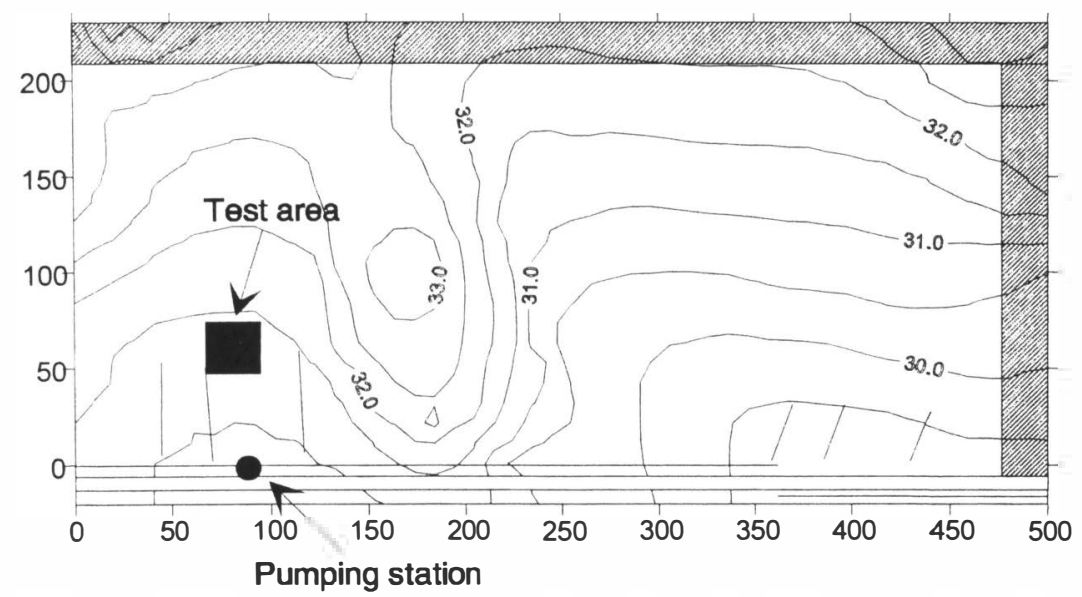

Figure 3. Elevation of surface covered by energy forest at Moskogen landfill in Kalmar including pumping station and future sub-surface for special tests. 


\section{The Hedeskoga landfill}

The Hedeskoga Waste Management site, occupying an area of 14 hectares in Hedeskoga located $3 \mathrm{~km}$ north of Ystad, has been in operation and serving the Municipality of Ystad since 1973. Since 197x this landfill has been operating under a certificate of approval from Swedish EPA to receive municipal solid waste, construction/demolition waste and industrial waste. Today, it receives waste from 3 communities (Ystad, Skurup and Sjöbo) representing 70000 inhabitants. This corresponds to about 20,000 tons of household waste annually, to which 20,000 tons of industrial wastes are added. The drainage system is separated into three sections. each draining waste of a different age. Until spring 1999 the leachate was lead to the municipal wastewater plant but since then the leachate is distributed on 5 ha of the old part of the landfill recently planted with willow (short rotation forest).

A artificial pilot-wetland has also been constructed on top of the landfill for research in order to improve the understanding of wetland water balances, treatment efficiency - both in the bed and in the bottom liner- and short and long term infiltration rates.

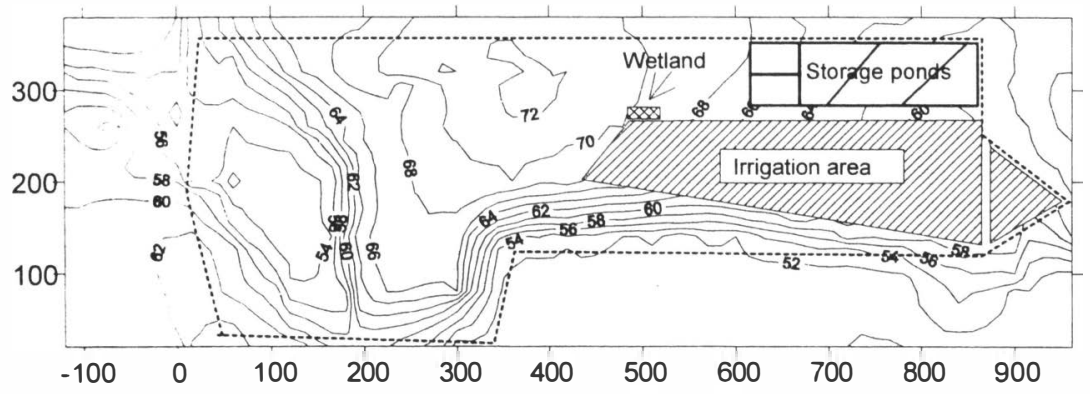

Figure 4 Elevation of the Hedeskoga landfill. Wetland test plant located on top of the landfill as well as the energy forest

Layout of the SP treatment system consists of five ponds and a parcel of land located on the southern part of the landfill planted with willows. Leachate is collected in two of the ponds and then pumped to a third aeration pond. Thereafter allowed to sediment in a fourth pond before distribution over the irrigation area. The three storage ponds having a total area of about 1 ha is sited on the drained landfill area. The irrigated area is approximately $100 \mathrm{~m}$ in width and $500 \mathrm{~m}$ in length having a surface area of about 5 ha.

\section{Characteristics of the leachate}

Leachate composition varies significantly among landfills, depending on waste composition, waste age, and landfilling technology. Moskogen and Hedeskoga are of similar age and the landfilled wastes are of the same type so in this case one can't expect large differences. 
Leachate generated at the Moskogen landfill has been monitored on a continuous basis since 1990 and at the Hedeskoga landfill since 1992. Key leachate parameters for Moskogen and Hedeskoga are presented in Table 1.

Table 1. Composition of leachate at Hedeskoga and Moskogen landfills

\begin{tabular}{l|cccccc}
\hline & $p H$ & $\begin{array}{c}\text { Conductivity } \\
\mathrm{mS} / \mathrm{m}\end{array}$ & $\begin{array}{c}\text { Chlorid } \\
\mathrm{mg} / \mathrm{BOD}\end{array}$ & $\begin{array}{c}\text { COD } \\
\mathrm{mg} /\end{array}$ & $\begin{array}{c}\text { TOC } \\
\mathrm{mg} / \mathrm{l}\end{array}$ \\
\hline & & & & & & \\
Hedeskoga & 7,0 & 457 & 660 & 50 & 610 & \\
Moskogen & 8.1 & 250 & 410 & 380 & & 110 \\
\hline
\end{tabular}

\begin{tabular}{l|cccc}
\hline & $\begin{array}{c}\text { Tot }-\mathrm{N} \\
\mathrm{m} / 1\end{array}$ & $\begin{array}{c}\mathrm{NH}_{4}-\mathrm{N} \\
\mathrm{mg} / \mathrm{l}\end{array}$ & $\begin{array}{c}\mathrm{NO}_{3}-\mathrm{N} \\
\mathrm{mg} / \mathrm{l}\end{array}$ & $\begin{array}{c}\mathrm{NOx-N} \\
\mathrm{mg} / \mathrm{l}\end{array}$ \\
\hline Hedeskoga & 340 & 320 & $0 . \mathrm{d} 9$ & \\
Moskogen & 66 & 59 & & 2.5 \\
\hline
\end{tabular}

\section{Results}

As the project started recently there are sparely with data to present. However, the pretreatment in the ponds seems to work at Hedeskoga. The reduction of pollutants was in July: BOD $80 \%$; COD $65 \%$; Tot-N $87 \%$ and $\mathrm{NH}^{4}-\mathrm{N} 94 \%$. No data is so far available for the reduction of pollutants at the irrigated area.

Pollutant reduction in the ponds at Moskogen is a little bit tricky to calculate, as there is two different types of leachate influent to the first pond. The samples are taken in this pond and when related to total leachate quality it may result in underestimation of reduction levels. Nevertheless the reduction for some key parameters are: BOD $97 \%$, COD $41 \%, \mathrm{NH}_{4}-\mathrm{N} 63 \%$

The quality of the drained water has not stabilised yet. Reduction after one week for parameters as ammonia-nitrogen and COD was $80 \%$ and $50 \%$ respectively. The colour of the drained water was improved and conductivity was half of the level in the irrigation water. Values of dissolved oxygen and redox-potential was low $(<0.5 \mathrm{mg} / \mathrm{l}$ and $-40 \mathrm{mV}$ respectively) in the drained water implying that anaerobic conditions prevail in the lower root zone. Most of the water from the lysimeters showed also low levels of oxygen $(1-4.5 \mathrm{mg} / \mathrm{l})$ and low redox-potentials $(-8-(-110) \mathrm{mV})$. 


\section{References}

Bengtsson, L., Bendz, D., Hogland, W., Rosquist, H. \& Åkesson, M. (1994), Water Balances for Landfills of Different Age. Journal of Hydrology, No 58, pp 203-214.

DOI: https://doi.org/10.1016/0022-1694(94)90054-X

Brix, H. (1994), Use of wetlands in water pollution control: Historical development, present status and future perspectives. Journal of Water Science and Technology 30(8):209-223. DOI: https://doi.org/1 0.2166/wst.1994.0413

Dilip, R., (1999), Lokal behandling av lakvatten i mark-växt-system (Local treatment of leachate in soil-plant system), Report in Swedish. Department of Water Resources Engineering, Lund University.

Ettala, M. (1987), Influence of irrigation with leachate on biomass production and evapotranspiration on a sanitary landfill. Aqua Fennica, No 17 (1) pp 69-86

Ettala, M. (1988) Short-rotation tree plantations and hydrological aspects in landfill management. Helsinki University of Technology, Laboratory of Hydrology and Water Resources Management. Report 1988/2 Otaniemi 13p. ISBN 951-754-628-9.

Hasselgren, K., ( 1992) Soil-Plant Treatment System. in Landfilling of Waste: Leachate, ed. Christensen, T. H., Cossu, R., Stegmann, R., Elsevier Appl. Science, England.

Witttgren, H., ( 1988), Removal of Wastewater Nitrogen in a Wetland Filter. Linköping University, Sweden, ISBN 91-7870-397-2. 